\title{
Phosphate-independent utilization of phosphonoacetic acid as sole phosphorus source by a psychrophilic strain of Geomyces pannorum P15
}

\author{
Magdalena Klimek-Ochab
}

Received: 1 July 2013 / Accepted: 27 January 2014 / Published online: 26 February 2014

(C) The Author(s) 2014. This article is published with open access at Springerlink.com

\begin{abstract}
A psychrophilic fungal strain of Geomyces pannorum $\mathrm{P} 15$ was screened for its ability to utilize a range of synthetic and natural organophosphonate compounds as the sole source of phosphorus, nitrogen, or carbon. Only phosphonoacetic acid served as a phosphorus source for microbial growth in phosphate-independent manner. Substrate metabolism did not lead to extracellular release of inorganic phosphate. No phosphonate metabolizing enzyme activity was detectable in cell-free extracts prepared from Geomyces biomass pregrown on $2 \mathrm{mmol} / \mathrm{L}$ phosphonoacetic acid.
\end{abstract}

\section{Introduction}

In the last few years, increased attention has been focused on a class of organisms called psychrophiles. Numerous organisms, prokaryotic but also eukaryotic, were found widely in natural and artificial cold environments (Georlette et al. 2004). They produce a variety of cold-adapted enzymes to carry out metabolism efficiently under cold conditions. A characteristic feature of many enzymes from psychrophiles is the correlation of high catalytic activity and low thermal stability at moderate temperatures, what allows to copy with the reduction of chemical reaction rates induced by low temperatures (Feller 2003). Naturally evolved psychrophilic enzymes require an improved flexibility of the structural components involved in the catalytic cycle, whereas other protein regions, if not implicated in catalysis, may or may not keep a high rigidity (Russell et al. 1998; Zhao et al. 2012). Various enzymes from psychrophilies and psychrotolerants have strong potential for

\section{Klimek-Ochab $(\bowtie)$}

Department of Bioorganic Chemistry, Faculty of Chemistry,

Wroclaw University of Technology, Wybrzeże Wyspiańskiego 27,

Wrocław 50-370, Poland

e-mail: magdalena.klimek-ochab@pwr.wroc.pl various biotechnological applications, such as biotransformation, bioremediation, and so forth.

Organophosphonates are substances characterized by the presence of a carbon atom covalently bound to a phosphorus atom. This very stable bond occurs in a number of industrial, agricultural, medical, and household cleaning products (Nowack 2003), a fact that is raising increasing concerns due to their possible negative environment impact (Fenner et al. 2013). Several microorganisms of different origin have evolved the ability to utilize organophosphonates as a nutritional source of phosphorus (Kononowa and Nesmeyanowa 2002; McGrath et al. 2013; Sviridov et al. 2012; Forlani et al. 2011; Luo et al. 2011; Fan et al. 2012). The catabolism of organophosphonic acids by the carbon-phosphorus (CP) lyase pathway of Escherichia coli and numerous other bacteria requires the gene product of the 14-cistron phn operon, and both mechanism of CP bond cleavage and genetics of this process is still extensively studied (Kamat et al. 2011; Kamat et al. 2013; Hove-Jansen et al. 2011; He et al. 2011; Jochimsen et al. 2011).

To date, only a few enzymes catalyzing phosphonate hydrolysis have been purified and characterized (McGrath et al. 2013; Klimek-Ochab et al. 2006). In most cases, phosphonate utilization by bacteria was found to depend upon the phosphate status of the cell with several species where the enzymes expression seem independent of the availability of other $\mathrm{P}$ source (Ford et al. 2010; Kulakova et al. 2003; McMullan and Quinn 1994).

Phosphonate utilization by microbes may be an important and potentially underestimated component of $\mathrm{P}$ biogeochemical cycling (Falkowski et al. 2008; Martinez et al. 2009; Van Mooy et al. 2009).

Phosphonoacetic acid (PA) can serve as a model substrate for studying the microbial cleavage of $\mathrm{P}-\mathrm{C}$ bond. The hydrolysis of PA to acetate and inorganic phosphate is catalyzed by PA hydrolase. This enzyme, isolated and characterized from 
some bacterial strains, is highly specific for its substrate and is neither repressed nor inhibited by the presence of high inorganic phosphate (Pi) level (McMullan and Quinn 1994). The protein from Pseudomonas fluorescens $23 \mathrm{~F}$ is a $\mathrm{Zn}^{2+}$ dependent enzyme consisting of two identical subunits (McGrath et al. 1999). PA-hydrolase activity was also detected in cell-free extracts of two environmental isolates of Curtobacterium sp. and Pseudomonas spp.

Although bacterial metabolism of PA has been extensively studied (Fox and Mendz 2006), much less is known about the ability of fungi to utilize this substrate (Klimek-Ochab 2008). We previously reported that several Penicillium species are able to utilize PA as the only source of phosphorus. The enzyme providing fungi with such a capability was also PA hydrolase. However, it appeared to be different from the bacterial one (Klimek-Ochab et al. 2003; Forlani et al. 2006). The fungal PA hydrolase is a $43-\mathrm{kDa}$ monomeric protein showing low affinity toward its substrate and high sensitivity to even mildly acidic $\mathrm{pH}$ values. Enzyme activity neither was required nor was stimulated by the presence of divalent cations (Klimek-Ochab et al. 2006).

The degradation process of phosphonic compounds was studied mainly in mesophilic microorganisms whereas little is known of the ability of extremophilic microbes to utilize these compounds. Indeed, the only documented reports describe thermophilic microbes (Obojska et al. 2002; Adams et al. 2008; Gomez-Garcia et al. 2011).

Degradation pathways have not been investigated in coldadapted organisms. In this paper, we report for the first time that a psychrophilic fungal strain of Geomyces pannorum $\mathrm{P} 15$ was able to utilize PA as a source of phosphorus in the phosphate-independent manner.

\section{Materials and methods}

\section{Microorganism}

The psychrophilic fungal strain named P15 was a generous gift from Prof. Marianna Turkiewicz (Institute of Technical Biochemistry, Technical University of Lodz). This microorganism was identified in the DSMZ laboratory (Germany). Sequencing of the rDNA ITS fragment revealed a similarity of $99 \%$ to G. pannorum NRBC 31776 and $98 \%$ to G. pannorum ATCC 11501. The strain of P15 was therefore identified as G. pannorum (Link) Sigler \& J.W. Carmich (MB 314399).

The filamentous fungus strain P15 used in this study is deposited in the Institute of Technical Biochemistry (Technical University of Lodz, Poland) collection of Antarctic microorganisms (http://snack.p.lodz.pl/ibtnew/en/ research.htm). It was routinely maintained on Czapek-Dox agar, which provided profuse sporulation suitable for inoculum collection.

Growth conditions

Degradation experiments were carried out with a modified Czapek liquid medium which consisted of: $30 \mathrm{~g} / \mathrm{L}$ sucrose, $0.5 \mathrm{~g} / \mathrm{L} \mathrm{MgSO}{ }_{4} \cdot 7 \mathrm{H}_{2} \mathrm{O}, 0.5 \mathrm{~g} / \mathrm{L} \mathrm{KCl}, 2.64 \mathrm{~g} / \mathrm{L}\left(\mathrm{NH}_{4}\right)_{2} \mathrm{SO}_{4}$, $0.01 \mathrm{~g} / \mathrm{L} \mathrm{FeSO}{ }_{4} \cdot 7 \mathrm{H}_{2} \mathrm{O}$, and $0.5 \mathrm{~g} / \mathrm{L} \mathrm{KH}_{2} \mathrm{PO}_{4} \cdot 7 \mathrm{H}_{2} \mathrm{O}$, pH 7.2. When appropriate, the carbon or phosphate source was omitted and replaced by filter-sterilized PA; in the latter case, the medium was buffered with HEPES-KOH ( 5 mmol/L, pH 7.2). Cultures were grown either in 15-cm Petri dishes containing $50 \mathrm{~mL}$ medium or at $135 \mathrm{rpm}$ in $250-\mathrm{mL}$ Erlenmeyer flasks containing $100 \mathrm{~mL}$ medium, which were inoculated with a spore suspension in $0.05 \%$ Triton X-100 to a density of $10^{4}$ spores per milliliter and incubated at $10{ }^{\circ} \mathrm{C}$. Mycelium was harvested by vacuum filtration onto filter paper. To evaluate fungal growth, filters were dried for $48 \mathrm{~h}$ in an oven at $70{ }^{\circ} \mathrm{C}$ for dry-mass determination.

Analytical methods

Phosphonoacetate residual concentration either in medium supernatants or in assay mixtures was determined by anionexchange high-performance liquid chromatography (HPLC) as described previously (Klimek-Ochab et al. 2003). Inorganic phosphate was quantified colorimetrically by means of the green malachite acid dye assay (Forlani 1997). Protein concentration was measured by the method of Bradford (1976), using bovine serum albumin as the standard. All determinations and treatments were carried out at least in triplicate; reported values are means $\pm \mathrm{SD}$ over replicates.

Preparation of cell-free extract and hydrolase activity assay

Cultures grown to mid-exponential phase were harvested by centrifugation, and the mycelium was washed twice with icecold Tris- $\mathrm{HCl}$ buffer $(50 \mathrm{mmol} / \mathrm{L}, \mathrm{pH} 7.2)$, ground in a mortar with quartz sand, and further disrupted in a Cole Parmer Torbeo 36800600 -W sonicator with $4 \times$ cycles of 30 s sonication and 2 min cooling. Cell debris was removed by centrifugation at $20,000 \mathrm{~g}$ for $15 \mathrm{~min}$ at $4{ }^{\circ} \mathrm{C}$. The supernatant was dialyzed against Tris- $\mathrm{HCl}$ buffer $(50 \mathrm{mmol} / \mathrm{L}, \mathrm{pH}$ 7.2) overnight and loaded onto a DEAE-Sephacel column equilibrated with the same buffer. Retained proteins were eluted with a minimal amount of buffer containing $250 \mathrm{mmol} / \mathrm{L} \mathrm{NaCl}$, and the resulting extract was assayed toward PA hydrolase activity.

To measure phosphonoacetate hydrolysis, the reaction mixture contained $50 \mathrm{mmol} / \mathrm{L}$ Tris- $\mathrm{HCl}$ buffer, $\mathrm{pH} 7.2,5 \mathrm{mmol} / \mathrm{L}$ $\mathrm{PA}, 1 \mathrm{mmol} / \mathrm{L} \mathrm{ZnSO}_{4}$, and a limiting amount of enzyme in a final volume of $100 \mu \mathrm{L}$. After an appropriate incubation 
Fig. 1 Growth of G. pannorum P15 in media containing inorganic phosphate or phosphonoacetic acid as $\mathrm{P}$ sources and fungal utilization of both substrates. Data are means \pm SD of three replication
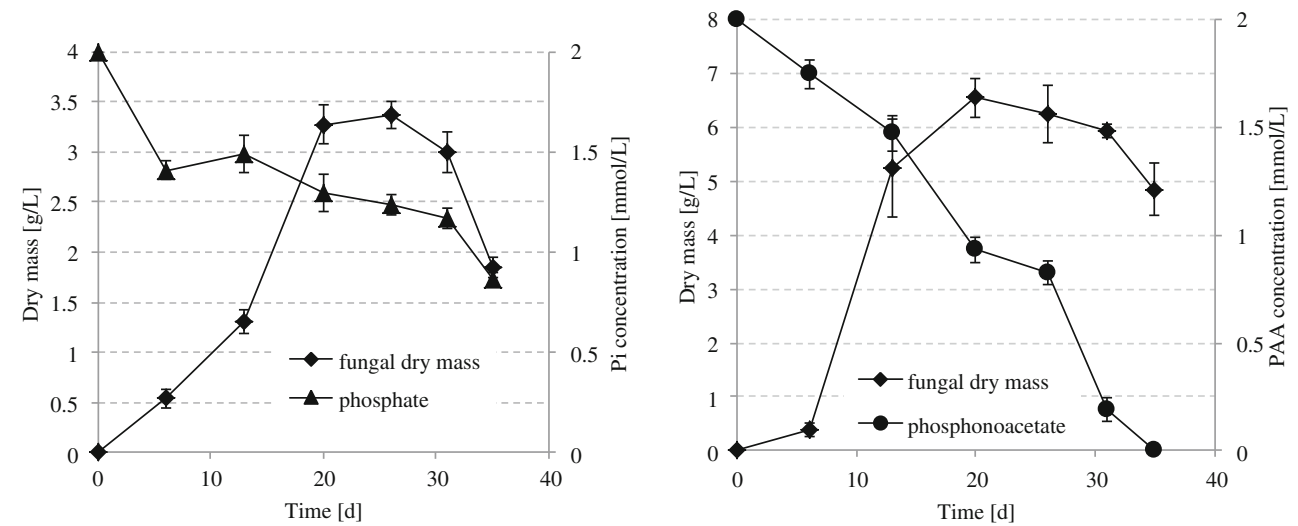

period (up to $60 \mathrm{~min}$ ) at $10{ }^{\circ} \mathrm{C}$, the inorganic phosphate released was quantified colorimetrically. Routinely, the hydrolase activity was expressed as the amount of phosphate released per second per milligram of protein.

\section{Results}

Phosphonoacetate utilization by Geomyces pannorum $\mathrm{P} 15$

Several psychrophilic fungal isolates were examined for their ability to utilize PA for cell purposes. Among them, a strain of G. pannorum $\mathrm{P} 15$ was found to grow in modified Czapek liquid medium containing the $\mathrm{PA}$ at $2-\mathrm{mmol} / \mathrm{L}$ concentration as the only source of phosphorus. Uninoculated controls showed no significant decomposition of the substrate. No phosphate release to the culture medium occurred during growth of G. pannorum on modified medium. Quite interestingly, biomass yields were much higher than those in complete medium (Fig. 1). In contrast no fungal growth was evident if the substrate was supplied as a carbon source.

Surprisingly, only the partial depletion of inorganic phosphate from the culture medium was observed in the case of non-modified medium, whereas complete utilization of PA occurred when phosphonate served as a P source. ${ }^{31} \mathrm{P}$ NMR analysis of fungal cell-free extracts showed the presence of PA $(\delta=16.52 \mathrm{ppm})$, proving the uptake and accumulation of the phosphonic substrate in the fungal cell.

Our study also found that PA utilization by psychrophilic isolate strongly depends on the temperature of fungal cultivation. HPLC analysis of culture supernatants clearly demonstrated that PA was removed most effectively at $10{ }^{\circ} \mathrm{C}$ (Table 1).

The effect of rising concentration of PA in culture medium on G. pannorum P15 growth was also studied. The concentration of PA up to $15 \mathrm{mmol} / \mathrm{L}$ stimulated the biomass production; however, no influence was observed when the substrate concentration exceeded this value (Table 2).
In the next step, the interference of Pi with PA utilization was extensively studied. Biomass yield and substrate utilization by fungal isolate were determined in media containing different combination of PA and Pi. Results are showed in Fig. 2.

Surprisingly, when the concentration value of inorganic phosphate was $2 \mathrm{mmol} / \mathrm{L}$ and the PA $5 \mathrm{mmol} / \mathrm{L}$ (in the cultivation medium, Fig. 2a), the concentration of both substrates decreased significantly with time of cultivation and biomass yield as well as growth kinetics were comparable with those obtained when psychrophilic strain was cultivated in medium containing only phosphonate substrate (Fig. 1). If inorganic $\mathrm{P}$ was available, but at very low concentrations $(0.15 \mathrm{mmol} / \mathrm{L})$, it was removed completely, with a very high rate during the first 5 days of cultivation (Fig. 2b), whereas PA utilization in such conditions do not exceed $25 \%$ of started value $(5 \mathrm{mmol} / \mathrm{L}, \mathrm{Fig}$. $2 \mathrm{~b})$. It is worth to stress that biomass yield obtained in these conditions was also much lower than in the case discussed above, see Fig. 2a.

In order to better characterize the ability to degrade carbonto-phosphorus bond by the fungal isolate, a series of structurally diverse phosphonates were tested. $N, N$ bis(phosphonomethyl)glycine, 2-aminoethylphosphonic acid, $\mathrm{N}$-phosphonomethylglycine, phenylphosphonic acid, and aminobenzylphosphonic acid failed to serve as a $\mathrm{P}$ source. Surprisingly, examined Geomyces strain was able to utilize

Table 1 Utilization of PA by Geomyces pannorum P15 at different temperatures of cultivation

\begin{tabular}{ll}
\hline Temperature of growth $\left[{ }^{\circ} \mathrm{C}\right]$ & Percent of substrate utilization \\
\hline 4 & 35 \\
10 & 52 \\
15 & 12 \\
20 & 2 \\
\hline
\end{tabular}

$2 \mathrm{mmol} / \mathrm{L}$ of PAA as the sole source of P. Final concentration of PAA was evaluated 20 days after inoculation. Data are means \pm SD over three replications 
Table 2 Utilization of PA by G.pannorum P15 cultivated on CzapekDox medium containing various concentrations of organophosphonate as the only source of phosphorus

\begin{tabular}{llr}
\hline $\begin{array}{l}\text { PA concentration in the } \\
\text { cultivation medium }[\mathrm{mmol} / \mathrm{L}]\end{array}$ & $\begin{array}{l}\text { mmol of PA/g } \\
\text { of biomass }\end{array}$ & $\begin{array}{l}\text { Biomass } \\
\text { yield [g/L] }\end{array}$ \\
\hline 2 & $0.27 \pm 0.08$ & $7.72 \pm 0.25$ \\
5 & $0.55 \pm 0.02$ & $9.26 \pm 0.12$ \\
10 & $0.62 \pm 0.11$ & $13.01 \pm 0.26$ \\
15 & $0.93 \pm 0.09$ & $14.26 \pm 0.18$ \\
20 & $0.94 \pm 0.02$ & $12.86 \pm 0.31$ \\
\hline
\end{tabular}

Final biomass and concentration of substrate were evaluated 35 days after inoculation. Data are means $\pm \mathrm{SD}$ over three replication

methylphosphonic acid, 1-amino-3-methylbutylphosphonic acid, and $N$-(phosphonomethyl)iminodiacetic acid supplied as a sole source of phosphorus with biomass yields exceeding
$5 \mathrm{~g} / \mathrm{L}$ after 20 days of cultivation. Degradation of phosphonic substrates utilized by fungal strains was confirmed by ${ }^{31} \mathrm{P}$ NMR analysis and no phosphonic products of degradation by Geomyces were detected during the time of experiment.

\section{Enzymatic activity of cell-free extract toward PA}

Since PA contains carboxyl group adjacent to its CP bond, it would be of particular interest to determine if the enzymatic mechanism of metabolism proceeds via hydrolase or CP lyase-like reaction. Many attempts have been undertaken to obtain enzymatically active crude extract of psychrophilic Geomyces strain. To establish the most efficient method of fungal cell lysis, fresh or frozen cells of psychrophiles were subjected to various disruption protocols (grounding in a mortar with liquid nitrogen, sonications, chemical treatment, and osmotic shock, data not shown). The mechanical method

(A)

$5 \mathrm{mM}$ PAA $+2 \mathrm{mM}$ Pi
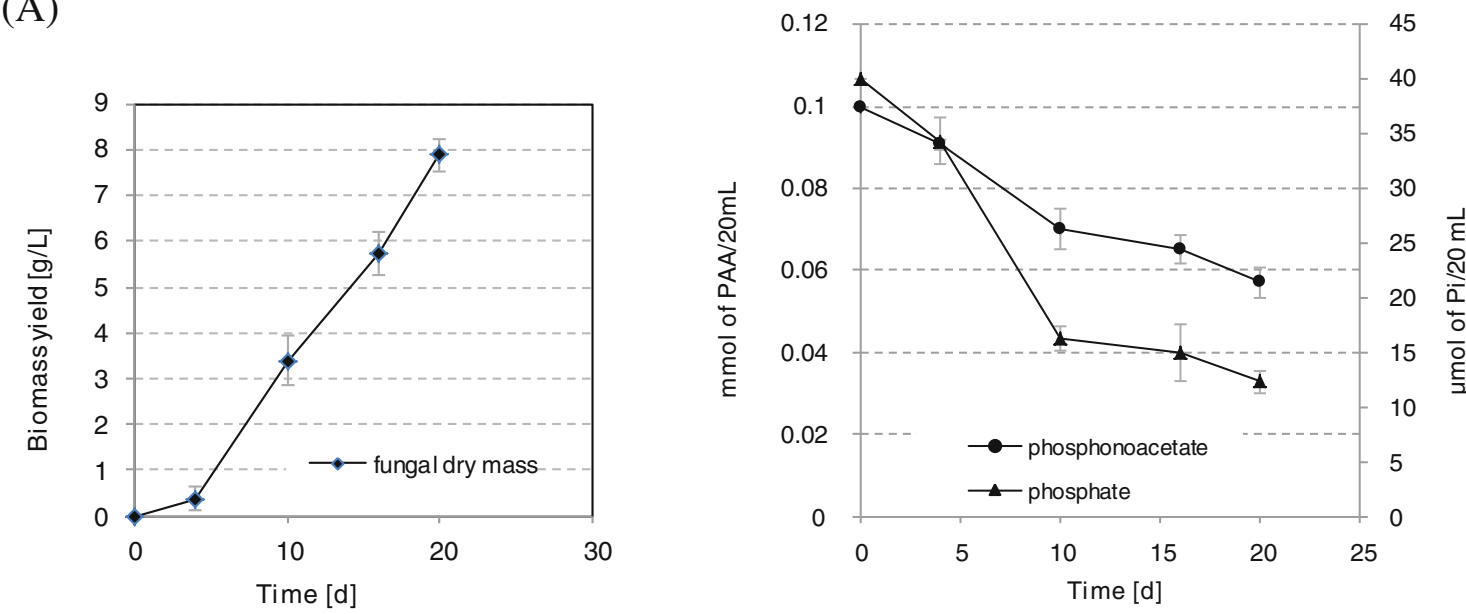

(B)

$5 \mathrm{mM}$ PAA $+0.15 \mathrm{mM}$ Pi

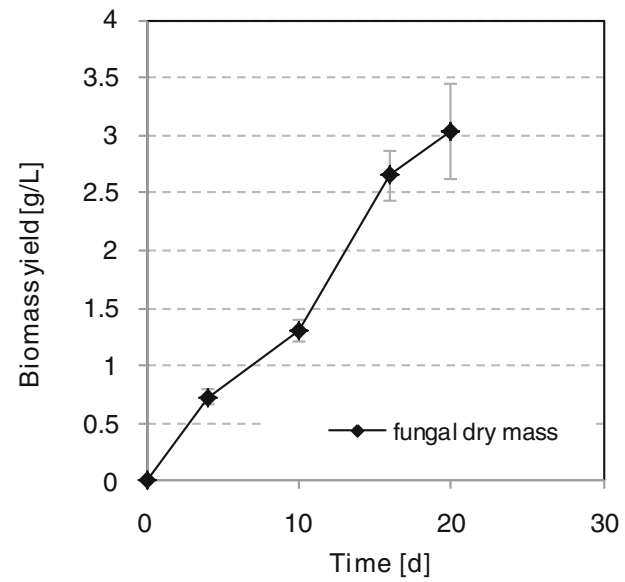

Fig. 2 Growth of Geomyces pannorum P15 in media containing inorganic phosphate and phosphonoacetic acid as $\mathrm{P}$ source. The residual concentration of both substrates in the broth supernatants was also

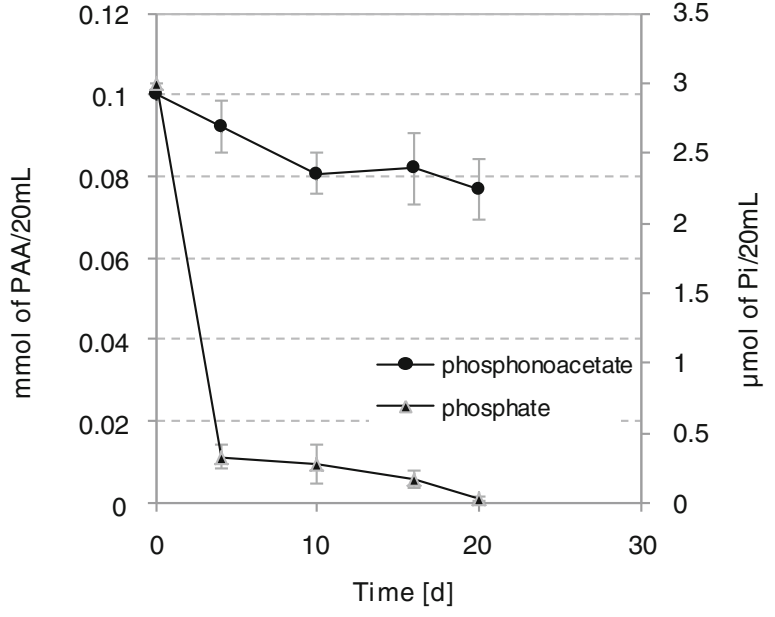

evaluated. Data are means $\pm \mathrm{SD}$ of three replication. a $5 \mathrm{mM}$ PAA+ $2 \mathrm{mM}$ Pi. b $5 \mathrm{mM}$ PAA $+0.15 \mathrm{mM}$ Pi 
sonication appeared to be the only one effective for disintegration of fungal cell-wall, and the level of released proteins was about $0.6 \mathrm{mg} / \mathrm{mL}$ of crude extract. Unfortunately, despite a number of attempts, no cell-free activity of enzyme(s) toward PA could be obtained.

\section{Discussion}

The present study proves for the first time that psychrophilic fungal strain $G$. pannorum P15 can cleave CP bonds and utilize phosphonacetic acid for growth. The degradation of substrate in fungal culture was complete only when PA served as a sole phosphorus source and appeared to be a temperaturedependent process. Raising the substrate concentration in the cultivation medium up to $15 \mathrm{mmol} / \mathrm{L}$ stimulated the fungal biomass production.

The acquisition of adequate supplies of $\mathrm{P}$ is a priority for all living cells. $\mathrm{Pi}$ is the preferred $\mathrm{P}$ source for cellular growth, and under conditions of Pi starvation, a number of gene systems whose products are involved in its acquisition and assimilation are induced (Quinn et al. 2007). It is worth to note that studied microorganism isolated from the synthetic phosphonate-intact environments possess some enzymatic mechanisms involved in the utilization of $\mathrm{P}-\mathrm{C}$-containing compounds. In the cold ecosystems, Pi concentration is sometimes in the subnanomolar range (Dyhrman and Haley 2006) and it is often, and increasingly (Karl 2000), the limiting nutrient. In such circumstances, the ability to access less readily available forms of organically complexed $\mathrm{P}$ would provide a competitive advantage for survival. The facility for PA utilization by fungal cells seemed to be a characteristic feature of adaptation of particular strain of Geomyces because among three tested strains of G. pannorum, only the isolate P15 was able to grow on this substrate used as phosphorus source in the cultivation medium. However, research has shown that laboratory cultures of G. pannorum isolated from various environments may exhibit extreme differences in morphology and physiology. In fact, the limits of cold adaptation of a particular isolate can vary depending on the source of isolation, even though the isolates are genetically identical (Kochkina et al. 2007).

The degradation of PA by psychrophilic strain has been found to be independent on the phosphate status of the cell. In the case of P15 strain, the utilization of P-C substrate in the presence of inorganic phosphorus in the cultivation medium exhibited quite unexpected course. If both phosphorus sources, namely, the inorganic phosphate and PA, are present in the medium at the sufficient levels, the utilization of phosphate occurs concomitantly with PA degradation. But, if inorganic phosphate was available at a very low level, the utilization of PA by Geomyces stopped after phosphate had been completely taken up by the cells. These results are distinctly different from those obtained previously in our laboratory with Penicillium strains, which were able to mineralize PA only in a phosphate-sensitive manner (Forlani et al. 2006).

Possibly, in the Geomyces cells, two independent transport systems for PA uptake exist. In the presence of inorganic phosphorus, phosphate transport into the cell is concomitant with PA transport across the cell envelopes. In the absence of $\mathrm{Pi}$, a different type of PA transport occurred. Both transport mechanisms cannot be active at the same time. Transport processes in fungi have been studied in only in the case of few different organisms with Saccharomyces cerevisiae and Neurospora crassa being the most frequently chosen experimental subjects and less often with Aspergillus nidulans. However, the significant differences in transport properties determined among these and other fungi indicate the great variety of physiological adaptations that have evolved among them. Considering the intimate contact that hyphae make with the environment and many different conditions to which fungi are adopted, it is not surprising that variation in transport system was found.

Mesophilic microorganisms utilizing the PA for cell purposes were found to possess active phosphonoacetate hydrolase in the cells. Different forms of this enzyme have been identified within the environmental microflora, as the enzyme occurs in both Gram positive and Gram negative bacteria as well as in filamentous fungi (Kononowa and Nesmeyanowa 2002; Forlani et al. 2006). Unfortunately, despite many attempts, no cell-free extract activity toward PA has been demonstrated in the case of psychrophilic Geomyces strain. The lack of detectable hydrolase activity can suggest presence of either cold-tolerant CP lyse-like enzymes or functioning of completely new enzyme(s) involved in PA mineralization by psychrophilic cells. It was generally believed that only one type of CP lyase exists, but the suggestion of Kertesz et al. (1991) that variant forms of the enzyme may occur has been confirmed (White and Metcalf 2004; McGrath et al. 2013). Further indication of the diversity of the enzyme system has come from in silico analysis which has identified homologous (occasionally multiple) CP lyase gene clusters across a wide range of prokaryotic groups; these show considerable structural and compositional variation (Huang et al. 2005).

Acknowledgments The work was financed by a statutory activity subsidy from the Polish Ministry of Science and Higher Education for the Faculty of Chemistry of Wrocław University of Technology

Open Access This article is distributed under the terms of the Creative Commons Attribution License which permits any use, distribution, and reproduction in any medium, provided the original author(s) and the source are credited. 


\section{References}

Adams MM, Gomez-Garcia MR, Grossman AR, Bhaya D (2008) Phosphorus deprivation responses and phosphonate utilization in thermophilic Synechococcus sp. from microbial mats. J Bacteriol 190:8171-8184

Bradford MM (1976) A rapid and sensitive detection method for the quantitation of microgram quantities of protein utilizing the principle of protein-dye binding. Anal Biochem 72:248-254

Dyhrman ST, Haley ST (2006) Phosphorus scavenging in the unicellular marine diazotroph Crocosphaera watsonii. Appl Environ Microbiol 72(2):1452-1458

Falkowski PG, Fenchel T, Delong EF (2008) The microbial engines that drive Earth's biogeochemical cycles. Science 320:1034-1039

Fan JY, Yang GX, Zhao HY, Shi GY, Geng YC, Hou TP, Tao K (2012) Isolation, identification and characterization of a glyphosatedegrading bacterium, Bacillus cereus CB4 from soil. J Gen Appl Microbiol 58(4):263-271

Feller G (2003) Molecular adaptations to cold in psychrophilic enzymes. Cell Mol Life Sci 60:648-662

Fenner K, Canonica S, Wackett LP, Elsner M (2013) Evaluating pesticide degradation in the environment blind spots and emerging opportunities. Science 341:752-758

Ford JL, Kaakoush NO, Mendz GL (2010) Phosphonate metabolism in Helicobacter pylori. Antonie Van Leeuwenhoek 97:51-60

Forlani G (1997) Properties of the 5-enol-pyruvyl-shikimate-3-phosphate synthase isoforms isolated from maize cultured cells. J Plant Physiol 150:369-375

Forlani G, Klimek-Ochab M, Jaworski J, Lejczak B, Picco AM (2006) Phosphonoacetic acid utilization by fungal isolates: occurrence and properties of a phosphonoacetate hydrolase in some penicillia. Mycol Res 110:1455-1463

Forlani G, Prearo V, Wieczorek D, Kafarski P, Lipok J (2011) Phosphonate degradation by Spirulina strains: cyanobacterial biofilters for the removal of anticorrosive polyphosphpsphonates from wastewater. Enzyme Microb Technol 48:299-305

Fox EM, Mendz GL (2006) Phosphonate degradation in microorganisms. Enzyme Microb Technol 40:145-150

Georlette D, Blaise V, Collins T, D'Amico S, Gratioa E, Hoyoux A, Marx JC, Sonan G, Feller G, Gerday C (2004) Some like it cold: biocatalysis at low temperatures. FEMS Microbiol Lett 28:25-42

Gomez-Garcia MR, Davison M, Blain-Hartnung M, Grossman AR, Bhaya D (2011) Alternative pathways for phosphonate metabolism in thermophilic cyanobacteria from microbial mats. ISME J 5:141-149

He SM, Wathier M, Podzelinska K, Wong M, McSorley FR, Asfaw A, Hove-Jensen B, Jia Z, Zechel DL (2011) Structure and mechanism of PhnP, a phosphodiesterase of the carbon-phosphorus lyase pathway. Biochemistry 50:8603-8615

Hove-Jansen B, McSorley FR, Zechel DL (2011) Physiological role of phnP-specified phosphoribosyl cyclic phosphodiesterase in catabolism of organophosphonic acids by the carbon-phosphorus lyase pathway. J Am Chem Soc 133:3617-3624

Huang JL, Su ZC, Xu Y (2005) The evolution of microbial phosphonate degradative pathways. J Mol Evol 61:682-690

Jochimsen B, Lolle S, McSorley FR, Nabi M, Stougaard J, Zechel DL, Hove-Jensen B (2011) Five phosphonate operon gene products as components of a multi-subunit complex of the carbon-phosphorus lyase pathway. Proc Natl Acad Sci U S A 108(28):11393-11398

Kamat SS, Wiliams HJ, Raushel FM (2011) Intermediates in the transformations of phosphonates to phosphate by bacteria. Nature 480 : $570-573$

Kamat SS, Williams HJ, Dangott LJ, Chakrabarti M, Raushel FM (2013) The catalytic mechanism for aerobic formation of methane by bacteria. Nature 497(7447):132-136

Karl DM (2000) Phosphorus, the staff of life. Nature 406:31-33
Kertesz M, Elorriaga A, Amrhein N (1991) Evidence for two distinct phosphonate-degrading enzymes (C-P lyases) in Arthrobacter sp. GLP-1. Biodegradation 2:53-59

Klimek-Ochab M (2008) Degradation of phosphonates by fungi. Curr Trends Microbiol 4:91-96

Klimek-Ochab M, Lejczak B, Forlani G (2003) A metal-independent hydrolase from a Penicillium oxalicum strain able to use phosphonoacetic acid as the sole source of phosphorus. FEMS Microbiol Lett 222:205-209

Klimek-Ochab M, Raucci G, Lejczak B, Forlani G (2006) Phosphonoacetate hydrolase from Penicillium oxalicum: purification and properties, phosphate starvation-independent expression and partial sequencing. Res Microbiol 157:125-135

Kochkina GA, Ivanushkina NE, Akimov VN, Gilichinskii DA, Ozerskaya SM (2007) Halo- and psychrotolerant Geomyces fungi from Arctic cryopegs and marine deposits. Microbiology 76(1):31-38

Kononowa SV, Nesmeyanowa MA (2002) Phosphonates and their degradation by microorganisms. Biochem Mosc 67:184-1952

Kulakova AN, Wisdom GB, Kulakov LA, Quinn JP (2003) The purification and characterization, of phosphonopyruvate hydrolase, a novel carbon-phosphorus bond cleavage enzyme from Variovorax sp. Pal2. J Biol Chem 278:23426-23431

Luo HW, Zhang HM, Long RA, Benner R (2011) Depth distributions of alkaline phosphatase and phosphonate utilization genes in the North Pacific Subtropical Gyre. Aquat Microb Ecol 62(1):61-69

Martinez A, Tyson GW, Delong EF (2009) Widerspread known and novel phosphonate utilization pathways in marine bacteria revealed by functional screening and metagenomic analyses. Environ Microbiol 12:222-238

McGrath JW, Kulakowa AN, Quinn JP (1999) A comparison of three bacterial phosphonoacetate hydrolases from different environmental sources. J Appl Microbiol 86:834-840

McGrath JW, Chin JP, Quinn JP (2013) Organophosphonates revealed: new insights into the microbial metabolism of ancient molecules. Nat Rev Microbiol 11(6):412-419

McMullan G, Quinn JP (1994) In vitro characterization of a phosphate starvation-independent carbon-phosphorus bond cleavage activity in Pseudomonas fluoresens 23f. J Bacteriol 176:320-324

Nowack B (2003) Environmental chemistry of phosphonates. Water Res 37(11):2533-2546

Obojska A, Ternan NG, Lejczak B, Kafarski P, McMullan G (2002) Organophosphonate utilization by the thermophile Geobacillus caldoxylosilyticus T20. Appl Environ Microbiol 68(4):2081-2084

Quinn JP, Kulakova AN, Cooley NA, McGrath JW (2007) New ways to break an old bond: the bacterial carbon-phosphorus hydrolases and their role in biogeochemical phosphorus cycling. Environ Microbiol 9(10):2392-2400

Russell RJM, Gerike U, Danson MJ, Hough DW, Taylor GL (1998) Structural adaptations of the cold-active citrate synthase from an Antarctic bacterium. Structure 6:3521-361

Sviridov AV, Shushkova TV, Zelenkowa NF, Vinokurova NG, Morgunov I, Ermakowa IT, Leontievsky AA (2012) Distribution of glyphosate and methylphosphonate catabolism systems in soil bacteria Ochrobactrum anthropic and Achromobacter sp. Appl Microbiol Biotechnol 93:787-796

Van Mooy BA, Fredrics HF, Pedler BE, Dyhrman ST, Karl DM, Koblizek M, Lomas MW, Mincer TJ, Moore LR, Moutin T, Rappé MS, Webb EA (2009) Phytoplankton in the ocean use non-phosphorus lipids in response to phosphorus scarcity. Nature 458:69-72

White AK, Metcalf WW (2004) Two C-P lyase operons in Pseudomonas stutzeri and their roles in the oxidation of phosphonates, phosphite, and hypophosphite. J Bacteriol 186:4730-4739

Zhao Y, Wakamatsu T, Doi K, Sakuraba H, Ohshima T (2012) A psychrophilic leucine dehydrogenase from Sporosarcina psychrophila: purification, characterization, gene sequencing and crystal structure analysis. J Mol Catal B Enzym 83:652-672 